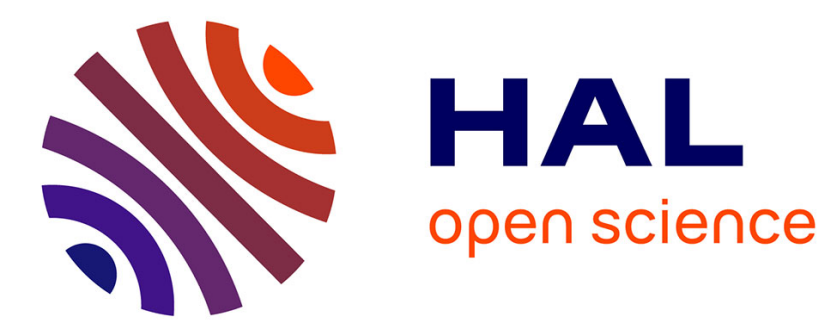

\title{
Note on the appearance of a new nucleocytoplasmic male sterility in Vicia faba after mutagenesis
}

Gérard Duc, Jean Picard, Joël Leguen, Pierre Berthelem

\section{To cite this version:}

Gérard Duc, Jean Picard, Joël Leguen, Pierre Berthelem. Note on the appearance of a new nucleocytoplasmic male sterility in Vicia faba after mutagenesis. Agronomie, 1985, 5 (9), pp.851-854. hal-00884821

\section{HAL Id: hal-00884821 \\ https://hal.science/hal-00884821}

Submitted on 1 Jan 1985

HAL is a multi-disciplinary open access archive for the deposit and dissemination of scientific research documents, whether they are published or not. The documents may come from teaching and research institutions in France or abroad, or from public or private research centers.
L'archive ouverte pluridisciplinaire HAL, est destinée au dépôt et à la diffusion de documents scientifiques de niveau recherche, publiés ou non, émanant des établissements d'enseignement et de recherche français ou étrangers, des laboratoires publics ou privés. 


\title{
Note on the appearance of a new nucleocyto- plasmic male sterility in Vicia faba after muta- genesis
}

\author{
Gérard DUC, Jean PICARD, Joël LEGUEN $(*)$ \& Pierre BERTHELEM (*) \\ I.N.R.A., Station d'Amélioration des Plantes, B.P. 1540, F 21034 Dijon Cedex \\ on behalf of Association des Créateurs de Variétés Fourragères (A.C.V.F.) \\ Etablissements BLONDEAU, B.P. 21, F 59235 Bersée \\ Etablissements CLAUSE, avenue L.-Claude, F 91220 Brétigny-sur-Orge \\ (*) I.N.R.A., Station d'Amélioration des Plantes, Centre de Recherches de Rennes, B.P. 29, F 35650 Le Rheu
} after mutagenesis with EMS and ethidium bromide. This new cytoplasm behaved differently when crossed with genomes that maintain or restore the $\mathbf{4 4 7}$ male sterility. The new cytoplasm also displayed instability.

Additional key words : Field bean, instability. après mutagenèse.

Après traitement mutagène au M.S.E. et bromure d'éthydium appliqué à une lignée mâle stérile cytoplasmique de Vicia faba à cytoplasme « 447 », un nouveau cytoplasme est apparu qui se comporte différemment par rapport aux génomes restaurateurs et mainteneurs de 447 et présente de l'instabilité.

Mots clés additionnels: Féverole, instabilité.

\section{INTRODUCTION}

Several authors have mentioned the occurrence of nucleo-cytoplasmic male sterility after mutagenic treatments :

\begin{tabular}{|c|c|c|}
\hline Species & Mutagenic treatmen & Authors \\
\hline Barley & EMS, $X$ rays & FAVRET \& RyaN (1964) \\
\hline Pearl Millet & $\begin{array}{l}\text { Ethidium bromide, } \\
\text { Streptomycin, } \\
\text { Mitomycin }\end{array}$ & BURTON \& HANNA (1976-1982) \\
\hline Sorghum & Colchicine & ERICHSEN \& ROSS (1963) \\
\hline Sugar beet & $\gamma$-rays & KINOSHITA (1976) \\
\hline
\end{tabular}

Modifications of a given cytoplasm by mutagenesis also occurred when lines of maize with the Texas male sterile cytoplasm were treated with $\gamma$-rays and Ethyl Methane Sulfonate (EMS) (CORNU et al., 1981). These modifications concerned reversions to fertility and dissociation of the characters of sterility and susceptibility to Helminthosporium maydis race $\mathrm{T}$. These changes could be related to modifications of the mitochondrial DNA (BERVILLE \& PAILLARD, 1982).
The 447 nucleo-cytoplasmic male sterility in Vicia faba was discovered by BOND et al. (1966). The instability of this character impaired its utilization for hybrid seed production. Seeking to modify this instability of male sterility, I.N.R.A. and the A.C.V.F. group used mutagenic treatments on the 447 cell lines.

\section{MATERIAL AND METHODS}

The mutagenic treatment was performed in 1978 at Dijon on a male sterile line carrying the 447 cytoplasm. This line, named Ad 23/447, was selected by P. BERTHELEM (I.N.R.A., Rennes). Seeds were soaked for $6 \mathrm{~h}$ in a solution of EMS $0.25 \%$ + Ethidium Bromide (EB) $0.05 \%$. Plants from these seeds were grown in rows in an isolated field plot with a restorer line sown in alternate rows. This restorer line named HG 115 (selected by P. BERTHELEM) carries the monogenic dominant factor controlling restoration of fertility. 
Male sterility of the line Ad 23/447 was confirmed by visual observation of one flower per plant in the isolated plot. These male sterile plants were harvested individually and hybrid progenies were sown the following year in different A.C.V.F. and I.N.R.A. stations.

Some scarce non-restored male sterile plants were then backcrossed with Ad 23 and HG 115. Their sister fertile plants were harvested after open pollination.

\section{RESULTS AND DISCUSSION}

Among 16000 hybrid plants studied, 100 expressed a good male sterile phenotype and were backcrossed by the restorer line HG 115. Sister plants of these male steriles were harvested after open pollination. In only one case after either controlled crosses or open pollination were male sterile plants observed in the next generation.

This case was analysed genetically (fig. 1). The male sterile character appeared to be maternally transmitted. Some wholy male sterile progenies were obtained either after crossing with HG 115 or Ad 23. However, in most cases, some male fertile plants were also observed in progenies. The following two features indicate that we obtained a new cytoplasm.

1. It reacted differently from the 447 cytoplasm with the restorer genotype HG 115 and also with the maintainer nucleus of 447 (table 1).

2. In the case of 447 cytoplasm, the reversion toward fertility resulting from instability or restoration was
TABLE 1

Results of $F_{1}$ crosses between male sterile plants carrying the " 421 " cytoplasm and maintainer lines of the ' 447 " cytoplasm. Male fertile/Male sterile segregation in progenies are indicated.

Résultats de croisements $F_{I}$ de plantes mâle stériles à cytoplasme « 421 » par les lignées mainteneuses du cytoplasme « $447 »$. Disjonctions mâle fertiles-mâle stériles.

\begin{tabular}{|c|c|c|c|}
\hline \multirow{2}{*}{$\begin{array}{c}\begin{array}{c}\text { "447" } \\
\text { maintainer } \\
\text { lines }\end{array} \\
\text { Ad } 23\end{array}$} & \multirow{2}{*}{$\begin{array}{l}\text { Main percentage of } \\
\text { fertile plants observed } \\
\text { in } F_{1} \text { on the " } 447 \text { " } \\
\text { cytoplasm }\end{array}$} & \multicolumn{2}{|c|}{$\begin{array}{l}\text { Number of plants in } F_{1} \\
\text { progenies on the " } 421 \text { ", } \\
\text { cytoplasm of phenotyp } \\
\text { Male fertile/Male sterile }\end{array}$} \\
\hline & & 0 & 11 \\
\hline & & 0 & 9 \\
\hline \multirow{2}{*}{ NY } & 0 & 14 & 4 \\
\hline & & 8 & 5 \\
\hline 135 & 0 & 3 & 12 \\
\hline \multirow[t]{2}{*}{123} & 2 & 22 & 18 \\
\hline & & 6 & 23 \\
\hline \multirow[t]{2}{*}{241} & 10 & 2 & 18 \\
\hline & & 2 & 15 \\
\hline \multirow[t]{2}{*}{249} & 10 & 1 & 23 \\
\hline & & 1 & 20 \\
\hline
\end{tabular}

permanent : no male sterile plants could be found in selfed progenies from these male fertile plants. In the case of this new cytoplasm, sterile plants could be found in the progenies from selfing.

This new cytoplasm was named 421 . In common with the induced modification of the Texas cytoplasm reported by CORNU et al. (1981) it showed instability of the sterile character in progenies. This instability was

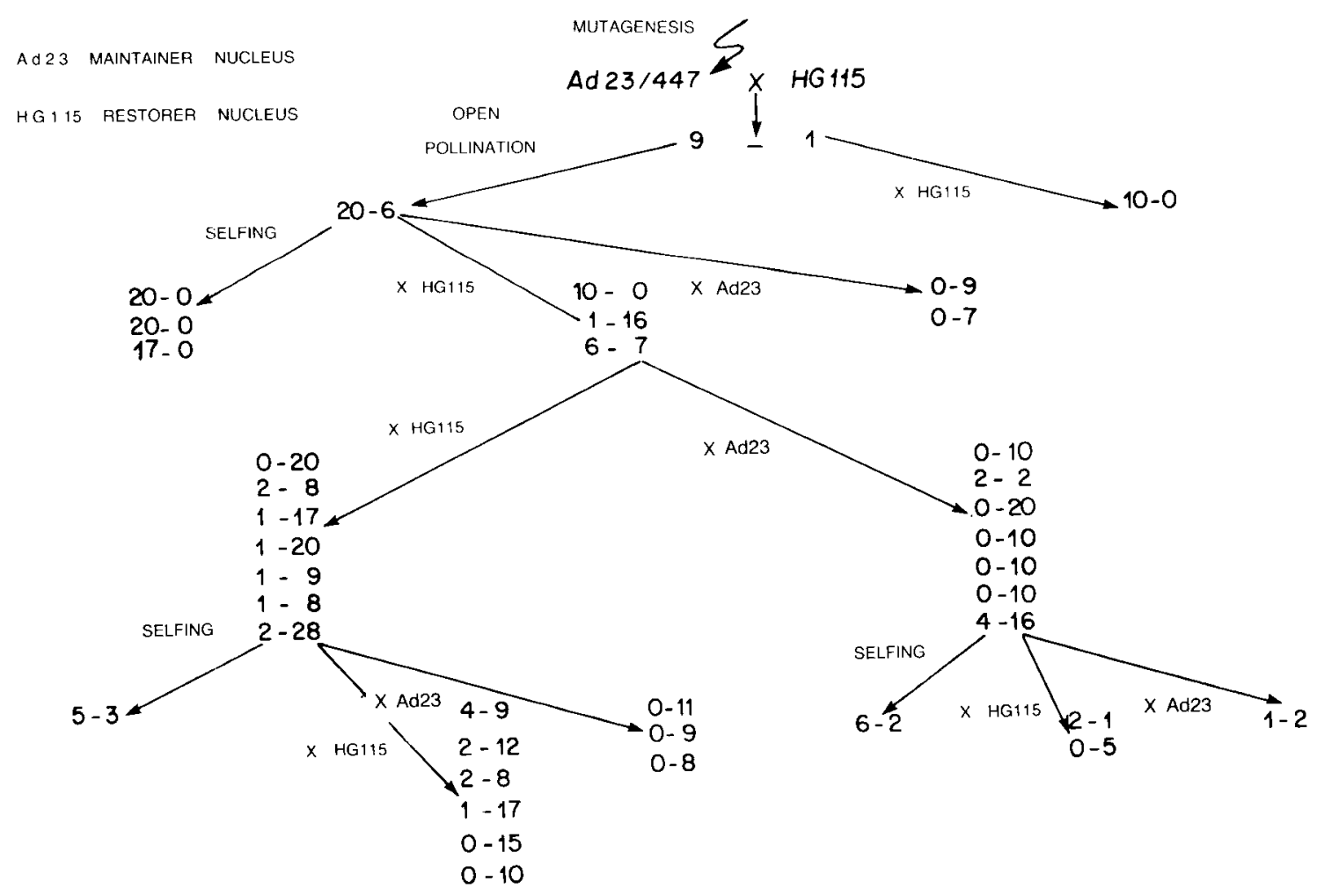

Figure 1

History of the 421 cytoplasm in Vicia faba. Male fertile-male sterile segregations in progenies.

Historique du cytoplasme 421 chez Vicia faba. Les disjonctions de plantes mâle fertiles-mâle stériles dans les descendances sont indiquées. Il s'agit de descendances en fécondation libre, autofécondation ou croisement par un mainteneur de 447 ( $\times$ Ad 23) ou restaurateur de 447 ( $\times$ HG 115). 
still noticed even after 4 generations of backcrossing (fig. 1). Instability could be explained by somatic segregation of some heterogeneity in the population of cytoplasmic organelles.

Future studies engaged by Dr BOUTRY in Louvain-laNeuve (Belgium) will characterize the mitochondria in the 421 cytoplasm. Up to now, no satisfactory restorer line of 421 is known and A.C.V.F. members are searching for them.

Reçu le 4 janvier 1985. Accepté le 9 mai 1985.

\section{REFERENCES}

Berville A., Paillard M., 1982. Comment améliorer chez le maïs (Zea mays L.) la résistance du cytoplasme Texas à Helminthosporium maydis race T et Phyllosticta maydis. Ed. I.N.R.A. Publ., Les Colloques de l'I.N.R.A., $\mathrm{n}^{\circ} 11,125-136$.

Bond D. A., Fyfe J. L., Toynbee-Clarke G., 1966. Male sterility in field bean (Vicia faba L.). III. Male sterility with a cytoplasmic type of inheritance. J. Agric. Sci. Camb., 66, 359-367.

Burton G. W., Hanna W. W., 1976. Ethidium bromide induced cytoplasmic male sterility in pearl millet. Crop Sci., 16, 731-732.

Burton G. W., Hanna W. W., 1982. Stable cytoplasmic male sterile mutants induced in Tift 23 DB1 pearl millet with mitomycin and streptomycin. Crop Sci., 22, 651-652.
Cornu A., Vuillaume E., Bodergat R., 1981. Intérêt des variants cytoplasmiques en amélioration des plantes: In "Induced mutations - a tool in plant breeding". IAEA-SM. 251/8, 267-275.

Erichsen A. W., Rosse J. G., 1963. Inheritance of colchicineinduced male sterility in sorghum. Crop Sci., 3, 335-338.

Favret E. A., Ryan G. S., 1964. Two cytoplasmic male sterile mutants induced by X-rays and EMS. Barley Newsletter, 8, 42.

Kinoshita T., 1976. Genetical studies on cytoplasmic male sterility induced by gamma ray irradiation in sugar beets. Jap. J. Breed., $26,256-265$. 